were more likely to use online services than clinic services. Females were more likely to use online services than clinic services when compared to males $(\mathrm{OR}=1.55, \mathrm{p} \leq 0.001)$. When compared to residents of white ethnicity, residents who identified as Asian $(\mathrm{OR}=0.74, \mathrm{p}=0.04)$, Black $(\mathrm{OR}=0.43$, $\mathrm{p} \leq 0.001)$ or Other $(\mathrm{OR}=0.48, \mathrm{p} \leq 0.001)$ were less likely to use online services than clinic services. When compared with heterosexuals, homosexuals $(\mathrm{OR}=1.46, \mathrm{p} \leq 0.001)$ and bisexuals $(\mathrm{OR}=3.10, \mathrm{p} \leq 0.001)$ were more likely to use online services than clinic services.

Conclusion There are demographic differences between residents that access online services and those that access clinic services. These data and more up to date data will be presented at the conference.

\begin{tabular}{|c|c|c|c|c|}
\hline $\begin{array}{l}\text { Demographic } \\
\text { variable }\end{array}$ & $\begin{array}{l}\text { Clinic users } \\
\mathbf{n}(\%)\end{array}$ & $\begin{array}{l}\text { Online users } \\
\mathrm{n}(\%)\end{array}$ & $\begin{array}{l}\text { Total } \\
\mathrm{n}\end{array}$ & $\begin{array}{l}p \text { value } \\
\left(X^{2}\right)\end{array}$ \\
\hline \multicolumn{5}{|l|}{ Ethnicity } \\
\hline \multirow[t]{2}{*}{ White } & 3,285 & 1,939 & 5,224 & $<0.001$ \\
\hline & (62.88) & (37.12) & & \\
\hline Mixed & $369(59.23)$ & $254(40.77)$ & 623 & \\
\hline Asian & $172(71.07)$ & $70(28.93)$ & 242 & \\
\hline \multirow[t]{2}{*}{ Black } & 1,991 & $442(18.17)$ & 2,433 & \\
\hline & $(81.83)$ & & & \\
\hline Other & $360(79.30)$ & $94(20.70)$ & 454 & \\
\hline Not Known & $516(100.00)$ & $0(0.00)$ & 516 & \\
\hline \multicolumn{5}{|l|}{ Age group } \\
\hline $16-20$ & 717 (80.02) & 179 (19.98) & 896 & $<0.001$ \\
\hline \multirow[t]{2}{*}{$21-25$} & 1,664 & 855 (33.94) & 2,519 & \\
\hline & $(66.06)$ & & & \\
\hline \multirow[t]{2}{*}{$26-30$} & 1,726 & 1,001 & 2,727 & \\
\hline & (63.29) & (36.71) & & \\
\hline \multirow[t]{2}{*}{$31-35$} & 1,067 & $408(27.66)$ & 1,475 & \\
\hline & (72.34) & & & \\
\hline \multirow[t]{2}{*}{$36+$} & 1,523 & $356(18.95)$ & 1,879 & \\
\hline & (81.05) & & & \\
\hline \multicolumn{5}{|l|}{ Gender } \\
\hline \multirow[t]{2}{*}{ Male } & 3,107 & 1,036 & 4143 & $<0.001$ \\
\hline & (74.99) & $(25.01)$ & & \\
\hline \multirow[t]{2}{*}{ Female } & 3,590 & 1,763 & 5,353 & \\
\hline & $(67.07)$ & $(32.93)$ & & \\
\hline \multicolumn{5}{|c|}{ Sexual orientation } \\
\hline \multirow[t]{2}{*}{ Heterosexual } & 5,439 & 2,268 & 7,707 & $<0.001$ \\
\hline & $(70.57)$ & $(29.43)$ & & \\
\hline Homosexual & 927 (70.28) & $392(29.72)$ & 1,319 & \\
\hline Bisexual & 109 (43.95) & $139(56.05)$ & 248 & \\
\hline Unknown & $222(100.00)$ & $0(0.00)$ & 222 & \\
\hline \multirow[t]{2}{*}{ Total } & 6,697 & 2,799 & 9,496 & \\
\hline & $(70.52)$ & $(29.48)$ & & \\
\hline
\end{tabular}

\section{P073 IF HIV-PREP IS MADE AVAILABLE IN ENGLAND, WHAT ARE THE RESOURCE IMPLICATIONS FOR GUM CLINIC SERVICE PROVIDERS?}

Koh Jun Ong*, Nigel Field, Holly Mitchell, Sarika Desai, O Noel Gill. Public Health England, London, UK

10.1136/sextrans-2016-052718.127
Background Under plausible assumptions, HIV-pre-exposure prophylaxis (HIV-PrEP) is cost-effective for high-risk MSM in England. There is consensus that HIV-PrEP should be delivered via quarterly GUM clinic attendances. BASHH recommends quarterly STI screening for high-risk MSM. An HIV-PrEP policy would have direct (extra consultation time and renal function tests) and indirect (additional STI/HIV screening) GUM clinic resource implications, as well as drug costs.

Aims To explore clinic costs if HIV-PrEP is introduced.

Methods Indirect clinic costs per person per year (PPPY) used the draft $2016 / 17$ National Tariff ( $£ 104 /$ follow-up GUM visit). Direct HIV-PrEP-specific clinic costs were estimated by microcosting. Direct tenofovir/emtricitabine costs used BNF prices ( $£ 12 /$ tablet), assuming $50 \% / 50 \%$ daily/intermittent dosing. GUMCADv2 provided numbers of eligible MSM and likely additional clinic attendances.

Results MSM, clinically assessed as high-risk, currently attend GUM services twice/year (median); for those given PrEP, two additional attendances would be required annually with indirect costs of $£ 208$ PPPY. In year one, the direct cost of starting HIVPrEP would be $£ 176$ PPPY, including an additional month- 1 follow-up. Clinical risk-assessment should result in offering HIVPrEP to 8,000 high-risk MSM annually. There is considerable turnover in this group, with $<10 \%$ remaining high-risk after two years. Assuming steady increases in coverage (from 2,000 in year one to 5,000 by year four), direct and indirect clinic costs would be $£ 0.8 \mathrm{M}-£ 2 \mathrm{M} /$ year and drug costs $£ 8 \mathrm{M}-£ 20 \mathrm{M} /$ year.

Discussion A national HIV-PrEP programme is likely to incur large drug costs but limited clinic costs. A substantially reduced drug price will be needed to enable wide coverage and maximise population impact.

\section{P074 BARRIERS ASSOCIATED WITH THE IMPLEMENTATION OF PROGRAMS FOR THE PREVENTION OF VERTICAL TRANSMISSION OF HIV}

${ }^{1,3}$ A.A.I.N Jayasekara*, ${ }^{2}$ D.A.C.L Dalugama, ${ }^{2}$ W.M.S.N.K Nawarathne, ${ }^{2}$ K.M.N.G.N Dias, ${ }^{3}$ O.B.W Rajapakse, ${ }^{2}$ S.D Dharmarathne. ${ }^{1}$ Brighton and Sussex University Hospitals, Brighton, UK; ${ }^{2}$ Faculty of Medicine, University of Peradeniya, Peradeniya, Sri Lanka; ${ }^{3}$ Faculty of Medicine, University of Sri Jayawardhanapura, Nugegoda, Sri Lanka, National STD control programme, Colombo, Sri Lanka

\subsection{6/sextrans-2016-052718.128}

Background Implementation of programs for the Prevention of Vertical Transmission of HIV(PVTHIV)/PMTCT faces higher degree of barriers and challenges at different levels.

Objective This pilot study is to examine the potential barriers that might affect the acceptability of interventions for in rural estate health care settings in Sri Lanka.

Methodology This is a cross-sectional study conducted among pregnant women in tea plantations where there are no programs for PVTHIV.

Results Of the 404 participants, 81\% (324/404) were tea estate workers, while 80 (19\%) were from nearby villages. Literacy rate among the respondents was high (88\%). Only 16\% knew about HIV/AIDS, 381 (95\%) did not know that a mother with HIV can pass the virus to her child and 390 (97\%) did not aware that HIV can transmit through breast milk. More than 95\% of participants agreed that they have enough access to basic antenatal care, including institutional delivery plan but none were aware of PMTCT services. Acceptability of a HIV test was high with $87 \%$ (337/404). Out of the women living with their marital partners (398/404,98\%), 68\% (264/398) preferred to 